\title{
THE NEW AGRICULTURAL POLICY OF SOVIET RUSSIA $^{1}$
}

\author{
Vladimir P. Timoshenko \\ UNTVERSITY OF MIOHIGAN
}

As we understand the new agricultural policy of Soviet Russia, it is the policy accepted by the communist party of Russia and put into effect after the fifteenth congress of the party in the winter 1927-28. Its purpose is to replace the small peasant farms by large-scale agricultural enterprises such as large state farms-sovkhoz-or cooperative farms, organized in a somewhat different manner, the so-called kolkhoz. During the last two years, 1929 and 1930, this policy has been put into effect with great vigor. In order to understand the reasons for this new policy, and the methods of its execution, it is necessary to give a short review of the agricultural policy of Soviet Russia beginning with 1917. To a certain degree the new agricultural policy of Soviet Russia is a return to the principles which dominated the agricultural policy of the Soviet government during the period of so-called war- or militant communism, from 1919 to 1921.

The Russian communist party, or the bolshevist group of the Russian social-democratie party, has always been a partisan of large-scale farming. It has always declared that in agriculture as well as in manufacturing large-scale enterprises have a competitive advantage over small ones and tend to supplant them. It does not recognize the existence of a special form of evolution in agriculture, different from that of industry.

However, the communist party, being a partisan of large-scale agricultural enterprise and not admitting any advantage in small farming, was, at the same time, quite conscious of the great popularity among Russian peasants of the idea of a subdivision of large estates and of a leveling of land holdings. Accordingly, in its struggle for power during the first steps of the revolution the communist party, in order to get the support of the peasantry, accepted an agricultural poliey which was not of its own making and did not correspond to its principles. In fact, the leaders of the left wing of the socialist-revolutionary party, with whom the communists had united their forces during the first steps of the communist revolution, were even permitted to formulate the first agricultural policy and to prepare the first agrarian law (the law of February 19, 1918).

1 Paper read at the joint meeting of the American Farm Fconomic Association and the American Statistical Aseociation at Cleveland, Ohia, December, 1930. 
The chief aim of this law was to create equalization in the use of land. It proclaimed that all ownership in land was abolished and that the land was transferred, for use, to all the working people; that all land was to be distributed on the principle of equalized land possession; and that every citizen in principle acquired the right to use the land. Thus the reform embraced not only the confiscated estates but the land of the peasants as well; "socialization" was to level all the existing inequalities of land possession.

The peasantry in its revolutionary activity did not follow exactly the principle of a thorough equalization of land through all the country but a considerable leveling of land holdings within narrower boundaries took place. Large estates were taken and subdivided, including all belonging to them-buildings, inventories, livestock, etc. The "surplus" lands from individual farms of wealthier peasants were also cut off and subdivided. But what is of greatest importance, all large-scale agricultural enterprises and even middle-sized farms, disappeared. In the entire country there was left in the hands of the Soviet government not more than two or three per cent of the arable and pasture lands. The land fell into the individual possession of the local population. But in spite of the extensive subdivision of large estates, the average size of peasant holdings did not increase appreciably. Many landless peasant householders obtained lands; even many city workers returning to the country obtained land; although the process of subdividing the larger peasant households proceeded very rapidly, the number of peasant householders increased likewise.

Such were the conditions when, early in 1919, the Soviet government, after the rupture with the left wing of the socialistrevolutionary party, tried to formulate its agricultural policy more nearly in accord with the principles of the communist party. The decree of February 14, 1919, declared the principles of the "socialistic organization or agricultural production." All land was proclaimed "a single state fund"; "all forms of individual land possession" were declared "to be dying out"; "big soviet farms, communes, communal land cultivation, and other forms of associated farming" were pronounced to be "the best means toward organizing a farming system on socialist lines." According to this decree, the land reserve is to be used in the first place, for satisfying the needs of the soviet farms and communes; in the second place, for satisfying the needs of artels, 
associations and other collective farm units. Individual cultivators, desiring land as a means of subsistence, occupy only third place.

In this way the policy of preference of state farms and of collective farms was proclaimed by the Soviet government as early as the beginning of 1919. But at that time this policy could not be applied. As was mentioned above the Soviet government by this time held really only from two to three per cent of the arable land and pasture land, only the remnants of the former large estates, which had been to a great degree subdivided by the peasantry. The Soviet government could utilize for the organization of large state farms only these remnants of former large estates. Likewise the "communes" (collective farms) were organized mostly on the land previously belonging to large estates. The peasants at this time were unwilling to depart from lands which they had taken from large estates or to organize their own farming on collective lines.

The attempts of the Soviet government to retain from ten to twelve million acres of land taken from large estates connected with sugar factories already nationalized by the Soviet government, and to organize on these lands large state farms for the production of sugar beets was unsuccessful. It succeeded in keeping only two or three million acres, the rest being held by the peasantry in small lots.

Thus the first attempt to organize a large farming enterprise in the form of state farms or collective farms was unsuccessful. Only a small percentage of the agricultural area, not more than 2 per cent of the total tillable land, was held by state farms and by communes, and even these few large farms were not successful. This is recognized even by official historians of the Soviet agricultural policy. One of them, Mr. Swidersky, in the article written in connection with the tenth anniversary of the Soviet government ${ }^{2}$ says that from four to five thousand state farms containing about five million acres and located in all provinces of Soviet Russia, could not produce sufficient food even for their personnel and for their livestock. They rented more than half of their land to peasants. ${ }^{3}$ After the introduction of the new economic policy (NEP) in 1921, many of these state farms were abandoned because they could not continue without financial help

\footnotetext{
2 Swidersky, A. T. Agrieultural policy over a period of 10 years. "Puti Selskogo Khoziaistva," official periodical of the Commixsariat of Agriculture, 1927, $\mathrm{N}$ 10, pp. 18-49.

Which shows that small-scale peasant farming at that time was more efficient than farming in large state farms.
} 
from the state whereas the policy of the state was to keep them on a self-supporting basis.

The collective farms of this period were not much more successful in spite of the fact that they obtained buildings and part of their livestock and inventories by confiscating them from large estates. By May of 1921 there were about fourteen thousand such collective farms with about three and a half million acres of land. During the period from 1921 to 1926 the number of collective farms and their agricultural area decreased rather than increased. At the beginning of 1927 official statistics estimated the number of collective farms at from fourteen to fifteen thousand and the land involved at from five to six million acres but with only 1,700,000 acres of crops, while the total crop area of the country was estimated at 280,000,000 acres. That is, collective farms produced a little more than a half of 1 per cent of the total crops. Together with state farms they accounted for only a little more than 1 per cent of the total crop area of the country.

Thus during that period of revolution the Soviet government was quite unsuccessful with its first experiments in large-scale farming. As it was several times officially stated, state farms were too far from the ideal to serve as examples of efficient and rationally organized farming for the neighboring peasantry. They could not produce for the government even a small part of the food necessary for city population. The government was obliged to confiscate all the food necessary for the city population from the small peasant farms. It is known that this policy of confiscating all the agricultural surpluses of the peasants was in a large measure responsible for the complete disorganization of agricultural production during the first period of the Russian revolution. It is not the purpose of this paper to discuss the agricultural policy of that period.

In 1921 the Soviet government was obliged to proclaim a new economic policy which was, likewise, a new agricultural policy. The prospect of an immediate socialistic organization of agriculture was abandoned. The Soviet government decided to leave more freedom of initiative to the peasants. The policy of confiscating all surpluses of agricultural products was replaced by fixed taxation of the peasants in kind. The market for agricultural surpluses was reopened. The purpose of the government was to stimulate the development of the productive activity of small- and medium-sized peasant farms, to increase their production beyond their needs for consumption, and to solve the food 
problem for the city population in this way. The best exposition of the agricultural policy of the period of NEP is probably the Land Code of 1922.

After proclaiming solemnly the principle of nationalization of land and the abolition of private rights to land, the Code of 1922 recognized practically unlimited tenure, in time, for agricultural use by the actual holders of the land. The Code did not impose on the peasantry new forms of land tenancy; on the contrary, it recognized the equality of all previously existing forms : the community of land, the individual holdings in open fields, and the holdings in closed fields (khutor or otrub). The Land Code, in abolishing private rights to land, without doubt did not permit such transactions as the purchase and sale, or mortgaging of land, but peasant's lands in Russia could not be freely sold or mortgaged even in pre-revolutionary times. Only after the agrarian reform of 1907 (Stolypin's reform) was it possible to establish full private property rights on allotted peasant lands. However, the Land Code of 1922 permitted the leasing of agricultural lands, though with certain limitations. It also permitted the use of hired labor in agriculture, which had been excluded by previous laws of the Soviet government. A few years later, in 1925, the Soviet government allowed even more freedom for leases of agricultural land: it permitted leases of twelve years' duration (even longer-two rotation periods if they were longer than six years). It also permitted rented land to be worked with hired labor. This had been forbidden by previous Soviet legislation and, without doubt, prevented the renting of land by the well-to-do peasantry. The use of hired labor in agriculture was still more facilitated by the temporary regulations of $\mathbf{1 9 2 5}$ concerning hired labor on peasant farms, for agriculture was permitted several exceptions from the regulations of the laws protecting hired labor, which are very severe in Russia. Agriculture, for instance, was permitted a longer working day-Ionger than eight hours.

It appears, then, that the policy of the Soviet government from 1922 to 1925 was to give some concessions to the peasantry, to conciliate the peasantry as a whole and to stimulate their productive activity. The food supply policy of the government was based on the production of small- or medium-sized peasant farms and it should be recognized that this agricultural policy was to a certain degree successful. During the period 1922-26 the Russian peasantry made a great effort to equal the pre-war and pre- 
revolutionary agricultural production. In 1922, the year of the greatest decline in agricultural production in Soviet Russia, the total crop area was only about 60 per cent of the pre-war area; in 1926 the total crop area of Soviet Russia was not very far below the pre-war level. ${ }^{*}$ That is, peasant agricultural production during the five year period increased about 50 per cent.

However, this policy of conciliating the peasantry did not continue long. The Soviet government clearly understood that in order to increase the quantity of marketable agricultural goods it had to favor well-to-do peasants, because only this group of peasants produced a considerable surplus of goods. A middle peasant produced for market a comparatively smaller percentage of his gross product and a poor peasant had practically no surplus. In order to have a sufficiently large surplus of agricultural products, large enough to cover the needs of the city population and to permit exports, the Soviet government had to favor the stronger farmer. But this was contrary to the political interests of the communist party and to its communistic scheme. The communist party considered the wealthier peasants as class enemies and that it had to fight against them to prevent their further growth and to keep them from power.

This conflict between the necessity of developing the productive forces of agriculture on the one hand and the communist policy on the other hand, caused continual vacillation in the agricultural policy of the Soviet government. The Soviet Government after 1922 made considerable effort to increase the productivity of agriculture, to supply the peasantry with agricultural machinery, to develop agronomic assistance, and to organize agricultural credit. On the other hand its taxation policy was more and more directed against the well-to-do peasant. The progression of agricultural taxes became so great that it prevented the increase in the size of farms and encouraged their subdivision into smaller units, which was detrimental to an increase in the productivity of agriculture.

The communist party became suspicious of well-to-do peasantry at a very early date. First there began the anti-kulak policy of the so-called "opposition" in the communist party (the group headed by Trotsky). This group demanded that the possi-

\footnotetext{
- The estimate of the total crop area of the U.S.S.R. by the State Planning Committee (Gosplan) is, for $1926,98.3$ per cent if 1913 equals 100 per cent. More cautious estimates by N. P. Oganovsky, an antbority on agrieultural statisties in Soviet Russia, put this percentage at 94.3 per cent, letting 1913 equal 100 . See article, "Decline, Recovery and Foconstruction of Agriculture during 10 Years," Ekonomicheskoe Obozrenie, 1927, No. 10, pp. $55-72$.
} 
bilities for growth of power of the well-to-do peasantry be limited. With this in mind, the opposition insisted upon decreasing agricultural prices in proportion to industrial prices so that a rapid industrialization of the country would be effected. At the same time the economic growth of the well-to-do peasants who were the principal sellers of agricultural surpluses would be retarded. The ruling group of the communist party did not oppose such a policy very long.

The low ratio of agricultural to industrial prices was perhaps more characteristic of Soviet Russia after the war than of any other country. The recovery of agriculture after 1922, thanks to the initiative of the peasants, was more rapid during the early part of this period than that of manufacturing which was controlled by the government. When later, industry had recovered its quantity production, it was not able to lower the cost of production sufficiently. As a result, the ratio of agricultural to industrial prices was always to the disadvantage of agriculture. Yet the intent of the Soviet governent was to keep this ratio on a low level.

Even the ratio of wholesale indexes of agricultural to industrial prices shows agriculture at a disadvantage.

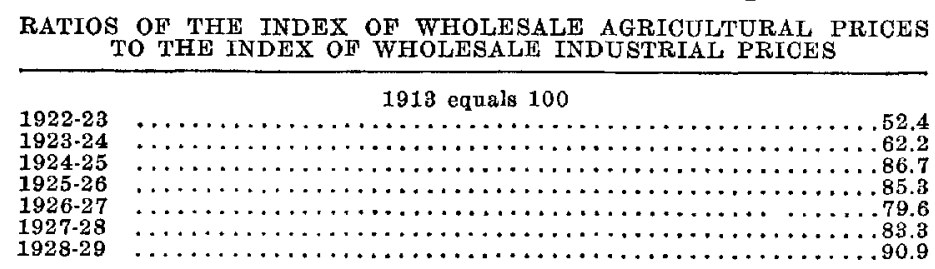

In 1924-1925 the ratio increased considerably, but this was due to the crop failure of 1924 .

A still greater discrepancy of prices is shown in the ratios of prices which peasants received for agricultural products to prices which they paid for industrial products. The so-called "peasant indexes," officially published by the Institute of Business Conditions, Commissariat of Finance, indicate that during the fall of 1926 these ratios were, for different agricultural regions, between 60 and 70 , while the ratio of wholesale prices was at the level of 80 to 85 - that is, the farmer received for his products in 1926-when the ratios had improved somewhat-not more than two-thirds and very often much less than what he received in 1913. It should be stated that the ratio of agricultural to

B The same study shows the ratios of prices paid for agricultural products by the govornmental purehasing organization to the index of retail prices. Such a ratio is published 
industrial prices in Russia before the war was also unfavorable for agriculture, on account of the great protection given to industry during that time. After the war an increase in the ratio of agricultural to industrial prices was greeted with approval in other countries and the policies of the governments were directed to that end. In Soviet Russia, on the contrary, when agricultural prices increased in 1924-25 (due to the crop failure) the government sought to lower them as soon as possible with the result that in 1925-26 and 1926-27 agricultural prices declined considerably.

An official study of the cost of production of small grains in Soviet Russia demonstrated that the return for a labor day engaged in the production of grain sold at prices prevailing during 1926-27 and 1927-28 was considerably below the wages of hired labor in agriculture. ${ }^{6}$

Unprofitable agricultural prices affected negatively all agricultural production but particularly that of the larger farms producing goods for market. The low percentage of marketable goods to total agricultural production was perhaps the greatest evil in agricultural conditions of post-war Russia. This percentage was low even before the war, and since the war it has declined considerably. Gosplan calculated that the percentage of all agricultural products sold on city markets to the total agricultural production was

$$
\begin{aligned}
& 22.2 \% \text { in } 1913 \\
& 16.3 \% \text { in } 1924-25 \\
& 16.5 \% \text { in } 1925-26 \\
& 16.9 \% \text { in } 1926-27
\end{aligned}
$$

Some specialists in agricultural statisties state that the estimated percentage of marketable goods for 1913 is perhaps too low and for the post-war years somewhat too high.? But accepting them as true, they show a considerable decline in the percentage of marketable products in agriculture. This is due to the subdivision of large estates and to the equalization of peasant farms. To a certain degree this decline is also the result of the price policy of the Soviet government.

Changes in the prices of one group of agricultural products as

by the State Planning Committee (Gosplan), showing that in 1925-26 a peasant received only 66.2 per cent of pre-war prices, and in 1926-27-63.7 per cent. See "Kontrolnye Tsifry for 1929-30," by Gosplan, Moscow, 1930, p. 580.

- Seo article, "Problems of Price Formation in Agriculture," by Sh. J. Turetskii, Planovoo Khoziaistro, 1929 , No. 6, p. 94.

Economic Bullotin of the Conjuncture Institute, 1927, Moscow, No. 11-12, p. 52. 
compared to another resulted in increase or decrease of production the next year. That the Russian peasant is very sensitive to this fluctuation in the price of different products, and regulates his crops accordingly may be illustrated by several examples. For instance, during 1925 and 1926 the prices of some intensive crops such as sunflowers and sugar beets, were fixed relatively lower than those for other agricultural crops, particularly grain. As a result, in 1926 the production of intensive and technical crops declined relatively to the grain production level. However, from 1927 on, grain prices dropped to the lowest of all agricultural products. This situation resulted in an increase of crop acreage of technical and intensive crops, while the grain crop acreage did not increase and even declined. Since 1927 Russia has had her greatest difficulties with the grain supply. ${ }^{8}$

In order to establish complete control of the agricultural market and of agricultural prices, the Soviet government during recent years (especially since 1925) has developed with increasing vigor a system of monopolization for the purchasing of agricultural products. For this purpose several administrative measures were passed in order to eliminate private competition completely from the agricultural market. In 1925 an order was issued by which grain and other agricultural products from private dealers were given the lowest ranking in the category of goods transported by rail. This meant practically the complete elimination of "private" agricultural products on the railroads. Somewhat later the railway rates for such private consignments were increased 50 to 100 per cent in comparison with what was charged for similar consignments of the state. Another condition unfavorable to private shipments was found in the fact that generally no shelter was available for "private" grain in railway stations. At the same time that the rates were increased, the government ordered complete nationalization of private flour mills. And a further step in this direction was taken when bank credit was forbidden to private persons engaged in the grain trade.

In this way private competition was practically eliminated in the purchasing of grain-although it was not forbidden by the law. Before the above-mentioned measures were put into effect "private" grain amounted to 20 to 22 per cent of all the grain transported by rail, while at the end of 1926 the transpor-

Economic Bulletin of the Conjuncture Institute N C Finance, Moscow, 1927, No. 11-12, pp. 50-51. 
tation of "private" grain amounted to only 1.5 to 2 per cent of all the grain transported by rail. ${ }^{\circ}$

The monopolization of the grain market was followed by the monopolization of other agricultural products. The government is now trying to monopolize the market for vegetables and for animal products.

Along with the monopolization of markets there was also developing the control of prices. The grain market was completely monopolized first, and then grain prices were lowered drastically in 1926. The index of grain prices from 161.1 in 1925-26 (1911-14 equals 100) was down to 124.6 in 1926-27 and was kept at the low level of 134.6 during 1927-28. The prices which governmental purchasing organizations paid were still lower.

The market of animal products was at that time (1927-28) less monopolized by the government and the index of prices of animal products continued to increase after 1925-26, although it was on a higher level in 1925-26 (1925-26-158.8, 1926-27-172.2, 1927-28-174.6). Consequently peasants tried to increase their production of those products for which the market was less monopolized by the state and at the same time they lowered the production of monopolized products. As a result the crop area of grains practically did not increase between 1926 and 1930 . The Soviet government encountered the greatest difficulties in procuring grain during the winter of 1927-28. After this time the Soviet government was obliged to resort to such methods of procuring grain as were practiced during the period of militant communism in 1918-27. Grains were not purchased at fixed prices but were requisitioned and if it was discovered that stocks were being concealed by peasants, they were confiscated and heavy fines (five times the value of the concealed grain) were levied upon the offenders. An implacable struggle against the well-todo farmer was proclaimed, the fifteenth congress of the communist party which was held during the winter of 1927-28 has formulated a new agricultural policy directed against the wellto-do peasantry, the so-called "kulak."

The fourteenth congress of the communist party, in 1925, had continued to grant some concessions to the well-to-do peasant (the above mentioned facilities for the rent of land and for the use of hired labor). The fifteenth congress on the other hand proclaimed an agricultural policy which was directed definitely against the well-to-do peasantry: there were introduced stricter

THensel, P., The Economic Policy of Soviet Russia, London, 1930, pp. 68.69. 
limitations for rent of land; leases longer than for six years were forbidden; "kulaks" were limited as to the use of hired labor; the inclosure of lands for individual farms was restricted or completely forbidden; the progression of agricultural taxes was made still greater.

However, the leaders of the communist party were fully aware that their agricultural policy could not be put into effect simply by limiting the activities of the well-to-do peasantry.

This practice alone would mean a decrease in the quantity of marketable agricultural goods, which up to this time had been produced mostly by the well-to-do peasantry; stagnation of agricultural production; and its degeneration to the production for home use only. ${ }^{10}$ It was necessary therefore to replace the production of the "kulaks" with the production of some organization which could be controlled and directed by the Soviet government. For this reason the fifteenth congress of the communist party passed a resolution favoring the stimulation of cooperation among agricultural producers, not only for marketing but especially for production. The same measures which limited the activities of the wealthier peasants favored at the same time the development of collective farming: the purchasing of agricultural machinery by well-to-do peasants was to be limited and this machinery was to be sold to the collectives; the granting of credit was to be refused to the well-to-do peasants, but it was to be extended more liberally to the collective farmers; the inclosure of lands by the individual well-to-do peasants was to be forbidden and at the same time the collective farmers were to be encouraged in the inclosure of their land, even though it might upset the production of individual farmers.

Furthermore, very soon after the fifteenth congress, the central committee of the communist party adopted a resolution (June, 1928) for the development of a very ambitious program of state grain farming. It was resolved to organize a grain trust, the organization to include many very large state farms which, during the following five-year period were to be developed to such a degree that they would yield yearly from $1,600,000$ to $1,700,000$ tons of marketable grain, mostly wheat.

Thus it appears that in 1927-28 the Soviet government returned to its old project of the development of large-scale farming

\footnotetext{
10 See "The Problem of Socialistic Reorganization of Agriculture," edited under the direction of Mr. J. A. Jakovleft, Moscow, 1928, preface, pp. XXVII-XXVIII. Mr. Jakovleff
actually is the Commissary of Agriculture of the U.S.S.R.
} 
along two lines; collective farms and state farms. We have seen that during 1919-21 this projeet had failed and the Soviet government had been obliged to renounce it. However, the Soviet government considered itself now better prepared to start once more. Then, too, the political reasons for their policy were perhaps more urgent than they had been at the time of the first experiment. The difficulties encountered in supplying the city population with grain, to say nothing about exports which had been discontinued early in 1927-28, demonstrated clearly to the Soviet government the danger of the situation. These difficulties had been caused mainly by the resistance of the well-to-do peasant to selling surpluses of grain, if any, at the low prices fixed by the government. These political considerations, more than any other reasons, induced the Soviet government to make itself independent of the well-to-do peasantry. The possibility of the development of agricultural production, based upon the initiative of the well-to-do peasantry was recognized as an alternative, but it was rejected for political reasons and because this way was considered capitalistic and incompatible with communist principles. ${ }^{11}$

The advocacy of such a "capitalistic" policy was laid by the ruling group at the door of the "right opposition" in the party. The ruling group itself accepted the policy of eliminating the individual well-to-do farmers and replacing them by large state and collective farms although even in 1928 the efficiency of the existing state farms was questioned by communist experts on agricultural problems such as the actual Commissary of Agriculture, and was considered to be lower than the efficiency of the large estates organized by landlords in pre-war times. ${ }^{12}$

The experience of 1919-21 had shown that it was impossible to take lands for state farms from the peasants in the greater part of European Russia. For this reason, from the beginning, the organization of large-scale grain production on huge state farms was planned for unoccupied lands in sparsely populated regions. In European Russia such unoccupied lands were to be found only in the regions east of the Volga and in the south-eastern corner, north of the Caucasus Mountains. These regions suffered the most from the famine of 1921 and the peasantry up to 1927 28 could not occupy all the land here. As early as September, 1928 , about 5,000,000 acres were set aside for the state grain

11 Op Cit., pp. XXVII-XXVIII.

12 Op. Cit., pp. XXVIII, 811-312. 
farms in this region. The other half of the planned 10,000,000 acres to be put into state farms for the territory of western Siberia and in the steppe region of central Asia. All these unoccupied lands may be characterized as semi-dry: the yearly rainfall in all these regions is from ten to fourteen inches. Also there are great fluctuations in precipitation from year to year. The settlement of the peasant population on such lands is a risky enterprise because failures of crops over several consecutive years are not infrequent and the support of a dense population on such lands during the periods of drought is a difficult problem. This is one of the reasons why from the beginning the state farms in these regions were planned to be wholly mechanized with a minimum of human labor and of livestock. All work was to be done by tractors and modern machinery, such as combines. The second reason for such an organization was that the Soviet government needed to obtain the largest possible surplus of grain from its farms. In order to utilize machinery and tractors most efficiently the state grain farms were planned to be of enormous size. By 1929 the average size of the 121 farms of the Grain Trust was given by official statistics at about 140,000 acres per farm. Many of them are much larger.

The first plan for the state grain farms, accepted in June, 1928 , contemplated an aggregate area of $10,000,000$ acres, with a total production of marketable grain of about $1,600,000$ to $1,700,000$ tons. But early in 1929 this project was more than doubled, for it was resolved during the five-year period to extend the area of state grain farms from 25,000,000 to $30,000,000$ acres, of which $17,000,000$ to $18,000,000$ acres were to be in regions east of Ural, 8,000,000 to $9,000,000$ acres in the basin of middle and lower Volga and in the North-Caucasian regions, and 4,000,000 to 5,000,000 acres in other regions of European Russia. In 1929-30, according to official data, 121 such farms were organized with a total area of $17,000,000$ acres, $2,500,000$ of which were under crops in the summer of 1930.

The execution of this project required from the State the investment of an enormous amount of capital. It was estimated that the organization and equipment of such farms, with a full suppy of tractors and modern tilling and harvesting machinery (mostly combines), would require about $\$ 15$ per acre. Many Soviet authorities considered this estimate too low. Experience with estimates on other constructive works in Soviet Russia had shown that generally actual costs of construction were much 
higher than preliminary estimates. But even accepting this estimate, the total investment in state grain farms would be not far from a half billion dollars.

It is difficult to estimate at this time how successful this ambitious project will be. Only two years have passed and it is, of course, only for this short period that we know the results. In the year 1930 the weather was favorable to dry farming and accordingly the yield must have been good, especially on prairie lands ploughed for the first time. As a matter of fact, most of the state farms were made up of virgin land. There are no reliable data as to costs of production on the state grain farms. It may be supposed that extensive small-grain farming on large farms supplied with modern machinery may be profitable if the management is efficient, but experience with state farms existing about 1919-20, in several regions of European Russia, indicated that generally their management was rather inefficient. Furthermore, in 1928 after several years of experience and reorganization, production on state farms was often less efficient than on small peasant farms. This situation was clearly recognized in 1928 by the director of the agricultural policy of Soviet Russia. ${ }^{13}$

This may be said quite definitely, even now, concerning the project of the Grain Trust: the investment by the state of enormous capital in such a hazardous enterprise may be considered very questionable at this time when Soviet Russia is suffering from a deficiency of capital for many other very important projects. It would be much more reasonable to encourage investments in agriculture by the peasants. State funds should be reserved for such projects as the development of transportation system, especially in new and sparsely populated regions; reclamation of lands, etc. But, as was said above, the policy of combating the well-to-do peasantry has discouraged them from savings and investments. As we shall try to show later, even the organization of collective farms is going on largely on account of investments made for the most part by the state. Furthermore, the recent agricultural policy of the Soviet government has resulted in a very serious disorganization of the livestock industry and now the Soviet government is obliged to start the new, and perhaps still more ambitious project, of organizing the animal industry on large state farms, united in trusts, such as "Skotovod" (cattle breeding trust), "Ovtsevod" (sheep breeding trust), "Svinovod" (hog-breeding trust), dairy trust,

13 See "The Problem of Socialistie Reconstruction of Agriculture," mentioned above, p. 822. 
etc. These new state enterprises may well require still larger investments. It seems that these new and unexpected investments in large agricultural enterprises are in a large measure responsible for the unbalanced financial situation in Soviet Russia last year and for the monetary inflation which exists unquestionably. And the depreciation of the monetary unit may put many new difficulties in the way of the agricultural developments of Soviet Russia.

The organization of large-scale collective farms is a second line of socialistic reorganization of the Russian agricultural system. It was stated above that during the period 1921-27 collective farms made little progress, and on the adoption of the new economic policy (NEP) these farms passed through a serious crisis. Unprepared for doing business on a monetary basis comparable with that of the ordinary cooperative farms with which they must compete, the communes and artels (different forms of collective farms) were broken up. According to statistics of the Central Statistical Office, out of 15,800 collective farms reported at the end of 1921, there remained by April, 1924, only 10,600. ${ }^{14}$ The decrease was greatest in those organizations which were most socialistic-the communes. The simpler voluntary associations for the tillage of the soil were reduced to a lesser degree. In 1924 the decline in the number of collective farms ceased, and there was even a slight revival - the total number of producing associations increasing in one year by nearly 25 per cent. In 1925 there were 13,100 small collective farms. After that time, however, they increased at a slower rate and on June 1, 1927, official statistics give the number of all forms of collective farms at 14,800, which is less than in 1921. The increase since 1925 was due entirely to the fact that a simpler type of association was set up with the result that since 1928 their number has practically trebled, while communes and artels have declined in number. By the middle of 1927 all forms of collective farms consisted of less than 1 per cent $(0.8 \%)$ of the total number of peasant households, and these sowed only 0.7 per cent of the total crop area. Thus their percentage of output in the total agricultural production of Soviet Russia was of minor importance.

During the period 1924-27 the government had granted some privileges to the agricultural collectives, such as tax reduction, special consideration in the supply of agricultural equipment,

34 Bulletin of the Central Statistical Office of the U.S.S.R. No, 102, July, 1925, pp. 73-75, and No. 116, Fob., 1926, pp. 117-118. 
preferential treatment in land settlement, and so on, but these privileges were no longer of the exclusive character which existed during the period when producers' associations were so much in vogue-1919-20. During this period official opinion itself did not estimate too highly the importance of collective farming. It recognized the advantages of communes and artels from the point of view of socialist theory but did not regard them as a "trunk road" toward socialism, but merely as a "branch road."

The situation changed completely after 1928. The Soviet government, after proclaiming its policy of eliminating the well-todo peasants, decided to replace their marketable surpluses of agricultural products by those of collective farms, and directed all its resources toward aiding these collectives, giving them innumerable privileges, and at the same time, depriving the wealthier individual farmers of all possibilities for development. The monopoly which it had of agricultural markets and of the system of distribution for industrial products gave enough power to the government to enable it to follow such a policy. The collective farms received considerable financial support in the form of eash credits and of special credits for the purchase of machinery. At the same time they obtained preferential treatment in the matter of purchasing machinery, while individual well-to-do farmers were limited in the machinery which they could buy. There were some kinds of machinery, such as tractors and other complex agricultural machinery, which it was not permissible to sell at all to the "kulak." The collective farms had also special privileges with reference to inclosing their land from community lands. This they could do at any time, without the approval of the community, even though this inclosure brought about a complete change in a recently established land organization of the community. (Decree, April 30,1928.) By a decision of the Soviet government, the bulk of the expenses involved in consolidating the land into collective farms was assumed by the state, while individual farms had to pay from their own resources at least part of such expenses. The tax payments of collective farms were considerably reduced. Often these farms were entirely exempted from the payment of certain taxes. The granting of loans to collective farms was so liberal that half or more of their means of production were acquired through state credit (survey of collective farms in 1928). Sometimes the credit obtained from the state exceeded the total value of the means of production of the collectives; that is, a part of the credit received 
by the collectives was used in the individual households of members. ${ }^{15}$

It must be emphasized that the progress of collective farming in Soviet Russia was not a spontaneous movement of the peasantry. It was based on the privileges granted by the government to collectives and was limited in its development by the amount of financial assistance which the government was ready to grant. This fact is quite openly recognized by the Council for Collective Farms of the U.S.S.R. ${ }^{16}$ Since in 1927-28 the Soviet government had more financial resources and could give more help to protected groups of peasants in the form of agricultural machinery than it had been able to give during 1919-20, the development of collective farming after 1927 was much more rapid and extensive. Using official statistics of the progress of collectivization in Soviet Russia the following table may be given:

DEVELOPMENT OF COLLECTIVE FARMS IN SOVIET RUSSIA

\begin{tabular}{|c|c|c|c|}
\hline \multirow[b]{2}{*}{ Date } & \multirow[b]{2}{*}{$\begin{array}{l}\text { Number of Col- } \\
\text { lective Farms } \\
\text { (In thousands) }\end{array}$} & \multicolumn{2}{|c|}{$\begin{array}{l}\text { Number of Households Members } \\
\text { of Collective Farms }\end{array}$} \\
\hline & & (In thousands) & $\begin{array}{c}\text { (In per cent of total } \\
\text { number of peasant } \\
\text { households) }\end{array}$ \\
\hline $\begin{array}{l}\text { June } 1,1927 \ldots \ldots \ldots \ldots \\
\text { June } 1,1928 \ldots \ldots \ldots \ldots \\
\text { June 1, } 1929 \ldots \ldots \ldots \ldots \\
\text { October } 1,1929 \ldots \ldots \ldots \ldots\end{array}$ & $\begin{array}{l}14.8 \\
33.3 \\
57.0 \\
67.4\end{array}$ & $\begin{array}{r}195 \\
417 \\
1.008 \\
1.919\end{array}$ & $\begin{array}{l}0.8 \\
1.7 \\
3.9 \\
7.4\end{array}$ \\
\hline
\end{tabular}

Over a period of less than two years and a half the number of peasant families involved in collective farming increased about ten times and by the fall of 1929 collective farms became a considerable factor in the agricultural activity of Soviet Russia.

It may be of interest to state that the growth of the idea of collective farming was not so rapid on all territory of Soviet Russia as in the regions of surplus production of small grain, such as the steppe area. Several reasons may be mentioned why collective farming developed more extensively and rapidly in the surplus grain producing regions. First, as we have seen, it was the policy of the government to increase the production of marketable grain by collectives because it was in the production of marketable grain that the government had met most of its difficulties. But there were other factors involved: crop production, and particularly small grain production, is the field where col-

15 See Gaister, A., "Dostizheniia i Trudnosti Kolkhoznogo Stroitelstra (The Results and the Difficulties of the Organization of Collective Farms), Moscow, 1929, pp. 33-34.

10 "Problems and Perspectives of the Organization of Collective Farms." The project of five-year plan for 1928-1932-33, Moscow, 1929, pp, 41-102. 
lective farming by a group of former individual small farmers, may have some technical advantages, especially if the collective farm is supplied with modern agricultural machinery, which the small individual farmers either lack completely, or cannot use efficiently on their small holdings. Exactly these conditions were found to prevail in the steppe regions of Russia where there was a large percentage of peasant households without working livestock and agricultural implements. This semi-proletarian peasantry had increased its land holdings during the revolution, it is true, but had not enough means of production at its command to work its land efficiently. The character of this semi-proletarian peasantry was also a factor. It must be borne in mind that in Soviet Russia the development of collective farming has not been a peaceful process. Its evolution has been a kind of class struggle. The government has tried to enlist the support of the proletarian and semi-proletarian groups in its struggle against the "capitalistic" elements in the country. In the steppe regions, with a sparser population composed largely of the well-to-do and semi-proletarian groups, the peasant class was, in general, less homogeneous than it was in the more densely populated regions of central Russia, and it was therefore easier to organize an internal class struggle by giving privileges to some and withholding them from others.

Furthermore, the method of farming in the steppe regions lends itself more readily to collectivization. It may be characterized as extensive since undiversified grain farming is predominant. The livestock industry is of secondary importance. All experiments with collective farming in Soviet Russia have shown that animal husbandry is the most difficult industry to collectivize and is least successful when accomplished. Generally speaking, collective farms are not stocked with livestock to the same extent as peasant farms and this is especially true with regard to cattle and other productive livestock. Individual peasant householders, joining collective farms, prefer to keep their cows, pigs, and sheep on their own individual farms. For this reason, the regions devoted largely to animal husbandry, as opposed to grain production, are less adaptable to collectivization. Therefore, government help in supplying machinery to collective farms in these regions is of minor importance since machinery is of little use in this industry. The advantages of machinery are not enough to counterbalance the disadvantage involved in the collectivization of the livestock industry. 
Quite recently, following the failure of the collectivization campaign in the livestock industry during the past winter, the Soviet government granted further privileges to the collective farms, favoring the collectivization of livestock. For example, it exempted from all taxation for two years the livestock of the members of collectives (see Resolution of the Central Committee of the communist party of April 2, 1930). If we take into consideration that the taxation of livestock of the individual farmers is very heavy and that it increases very rapidly with the increase in the number of head of livestock, the importance of the last privilege will be more evident.

We have tried to give some reasons for the rapid development of collective farming during the last two or three years. We shall now mention some of the limitations of this movement. One of the limitations has just been mentioned : collective farming develops more or less successfully only on crop farms. On the other hand, in animal husbandry collective farming up to the present has not been successful. For this reason the possibility of organizing collective diversified farming is questionable. It is true that there is a possibility of organizing collective crop farms, reserving animal husbandry to the individual households of the members of the collective farm. But it is against such a form of organization that the Soviet government contends. It fears that this practice would develop individualistic and capitalistic tendencies in some of the members of the group. Another difficulty is the fact that the development of specialized collective grain farms does not correspond well to the type of agriculture prevalent in many regions of Soviet Russia. Furthermore, the distribution of labor throughout a year is very uneven on the specialized collective grain farms, no better, in fact, than on the individual small farm of the same kind.

As a second limitation that may be mentioned collective farms up to 1929 were too small to use successfully and efficiently such modern machinery as tractors, combines, etc. They included on the average ten to fifteen families, with seventy-five to one hundred and twenty-five acres of crops, which is not larger than the average individual farm in America. All attempts of the Soviet government up to 1930 to increase the size of the collective farms were rather unsuccessful. In 1930 the size of the collective farms sharply increased, but about the methods of collectivization during the winter 1929-30 we shall speak later.

Collective farms are very unstable in their organization and 
their membership. The fluid character of the membership of collectives was emphasized by all official studies of collective farms. The turnover of membership in the collective farms is so large that they have been called ironically "house with thoroughfare." During each year of the period 1927-29, 15 to 25 per cent of the total membership left the collectives and was replaced by new members. At the same time yearly, about 20 to 30 per cent of the total number of collective farms were dissolved and new ones organized instead. Such an instability of membership and of the collective farms themselves without doubt, has interfered very much with a rational organization of farming. Official publications have frequently emphasized the fact that collective farming introduces a more rational crop rotation of from six to eight years' duration instead of the traditional three years' rotation more common on the individual peasant farms. However, this statement must be challenged as at least too premature, because after two or three years of experience it is difficult to say that a six to eight years' rotation has been really successfully introduced.

Too much hurry and precipitation is perhaps the greatest disadvantage in the campaign for collective farming in Soviet Russia. It was mentioned above that during 1927-28 the number of peasant households involved in collective farming increased about tenfold. But this tempo (this word is actually very much in vogue in Soviet Russia) is nothing compared to the development of collective farming in Soviet Russia during the winter of 1929-30. What happened during this winter is difficult to understand. From 1927 to 1929 the principal method of stimulating the development of collective farming was the granting of privileges to the collective farms and to their members as opposed to the individual farmers. During the winter of $1929-30$ the Soviet government, anxious to replace the production of the wellto-do peasantry by that of the collectives, and to "exterminate" the kulaks as a class, resorted to administrative coercion and pressure on the peasantry to compel them to join collective farms. The fact of coercion and pressure was officially recognized by Stalin himself, in his letter of March 2, 1930. In this letter, and in further publications of the communist press, numerous examples were given of stringent administration measures used by local administrative officers to force peasantry into collectives. Stalin tried to disparage these measures and to make the local administration responsible for them. However, it is 
difficult to believe that in Soviet Russia with its complete centralization it was possible for the local administration over a period of months to continue a policy which was contrary to the plans of the central government. It seems evident that it was the policy of the central government and that it was only when it produced very dangerous unrest in the country that it was decided to retract a little and to put the responsibility on the local administration.

The pressure on the middle peasantry to join collectives was accompanied by a bitter struggle against the wealthier peasantry, the kulaks, by confiscation of all their property, and by expelling them from their residences.

To accept the wealthier peasants as members in collective farms was forbidden. They could not be accepted as simple workers on collective farms even after wholesale confiscation of their property. The fact that a cruel class struggle was waged and that the property of the kulaks was confiscated has been officially admitted, but the policy of the communist press has been not to go much into the details. However, it is quite clear that during the winter of 1929-30 a real civil war raged through Russian villages. This social revolution which swept over the country during that winter may turn out to be the most important since 1917.

The speech of the actual Commissary of Agriculture of the U.S.S.R. at the sixteenth congress of the communist party ${ }^{17}$ gave some interesting statistics as to the amount of confiscation of property from "kulaks." He stated that by the summer of 1930, 15 per cent of the capital of all collective farms consisted of property confiscated from "kulaks." This calculation related only to buildings, machinery, equipment and livestock. Land was not included. When we take into consideration the fact that by the summer of 1930 from 40 to 50 per cent of peasant households in some of the principal grain regions had become a part of the collective farm system and that the "kulaks" represent 3 to 5 per cent of the total number of peasant households, it may be understood what great losses were suffered by them. The "kulaks" lost also all, or the greater part of their land.

In the same speech Mr. Jakovleff stated that two-fifths of the capital of the collective farms was covered by state credit, so that about three-fifths of the total capital of collective farms was given by the state or represented confiscations of property of

Ir See daily paper of the communist party, "Pravda," No. 190, July 12, 1930. 
other peasants, who themselves were not admitted in the collective farm organization. Such were the "incentives" which brought the mass of semi-proletarian peasants to the collective movement.

The results of this double policy of coercion and of bribery were at first sight striking. 59.3 per cent of the total number of peasant households in Soviet Russia became members of the collective system on March $1,1930 .^{18}$ In some of the most important agricultural regions with surplus grain production, the percentage of collectivization was announced still higher-70, 80 , and 90 per cent. Thus, an agricultural organization which had existed for hundreds of years was radically changed in a few months, 25,000,000 peasant households being affected. However, this did not continue long. On March 2, 1930, Stalin published his famous letter which proclaimed that peasants were not to be forced into the collective system but could join them voluntarily, and there immediately began an outpour of forced peasants from collectives. Two months later, by May 1, 1930, official statistics ${ }^{18}$ showed that the percentage of collectivized peasant households was only 24.1 per cent, a decrease of more than one-half since March 1. On the other hand, there are some communist writers who doubt that many peasant households were actually members of the collective system on March 1, 1930, expressing their opinion that many of the collective farms were listed only on paper. ${ }^{20}$ Nevertheless, the process of the formation of "collectives" as well as their dissolution (even if only "paper" collectives) was not "painless." The second question raised was how many of the collectives reported on May 1, 1930, were real collectives. Statistics given out by the head of the Council of National Economy of Soviet Russia, Mr. Kuybyshev, show the percentage of collectivized peasant households on October 1,1930 , to be 21.5 per cent, ${ }^{21}$ that is, 2.5 per cent lower than on May 1, 1930. Is this an actual decline, or simply a matter of having more exact statisties on this question?

However, even if we accept the last estimate, this one-fifth representing collectivized peasant households can be a very important factor in the agricultural situation in Soviet Russia, especially if we take into consideration the fact that in the major

Is See article, "The Problems of Collectivization of the Country" by M. Kraer, Planovoe Khoziaistvo, 1930 , No. 5 .

19 See "Agricultural Statisties of the U.S.S.R.", published by the Lenin Academy of Agricultural Sciences (in English), Moscow, 1930, p. 42 .

${ }_{20}$ See above mentioned artiele of $\mathrm{M}$. Kraev.

21 Soe New York Times, December 1, 1930 . 
grain surplus regions this percentage is from thirty to fifty per cent. The question is only how vital are all these collectives. The fact that the percentage of collectivized peasant households may fluctuate during one year (from 7.4 per cent on October 1, 1929, to 59.3 per cent on March 1, 1930, and 21.5 per cent on October 1, 1930) indicates that the situation cannot be said to be stable yet. Methods of promotion of the collective farm system and the difficulties of organization are important factors governing the situation. The authoritative Soviet organization which controls collective farming in all the U.S.S.R. - the Council for Collective Farms-in its five-year plan for collectivization (1928-29 to 1932-33) recognizes these difficulties. For instance it states ${ }^{22}$ that it is impossible to create successful collective farms without furnishing them with tractors and modern agricultural machinery, yet only a small percentage (not more than 15 per cent) of recently organized collective farms have tractors and the other farms continue to work with peasant horses and peasant implements. The greater number of tractors are found on the state grain farms. The total number of tractors in Soviet Russia is not large, a liberal estimate placing them at 70,000 to 75,000 on October 1,1930 .

The same Council recognizes that the organization of large collective farms is a much more difficult and complex problem than the organization of large state farms. It was estimated that for the collectivization of 16 per cent of the peasants' households during the five-year period, it would be necessary to engage a staff of eleven to twelve thousand college trained agriculturists, and it would be necessary to reorganize all agricultural education of Soviet Russia for this purpose (p. 81). However, one year later, in 1929-30, the Soviet government found it possible to collectivize a much greater percentage of peasant farms and accomplished this in the one year, though without a sufficient number of trained agriculturists, and before the reorganization of the agricultural colleges was completed.

The result was that the collective farms were insufficiently staffed with trained agriculturists and were without competent assistants to organize even the simpler forms of accounting. ${ }^{23} \mathrm{At}$ the same time, the size of these collective farms continued to increase so that, without question, they required the guidance of

\footnotetext{
${ }^{22}$ Op. Cit., p. 16. "Problems and Perspectives of the Organization of Collective Farms," Moscow, 1929 .

${ }^{23}$ See article, "In the Regions of Thorough Collectivization," by M. Solomonov, Planovoe Khoziaistvo, 1980, No. 2, Moscow, p. 289.
} 
experts, especially in organizing the work which, in the nature of the case, was radically different from the traditional form of peasant farming. On May 1, 1930, the collective farms, on the average, consisted of from sixty to seventy households, with a crop area of about 1,200 to 1,300 acres. In some of the regions much larger farms were found. The greatest difficulty encountered in the organization of these large collective farms resulted from the low level of intelligence of the Russian peasantry and the lack of trained specialists. The Soviet government mobilized coercively all college trained agriculturists and sent them to the collective "front" (making use of militaristic terminology). It is perhaps incorrect to speak of "forced" labor in connection with these trained specialists, but it is quite reasonable to designate this labor as "militarized."

What is especially dangerous for the stability of the new agricultural system in Soviet Russia-introduced in such a hurryis the fact that it was put into effect with coercive methods, the system being forced on the peasantry, and being accompanied by a cruel campaign against the well-to-do peasantry.

As a result, in organizing agriculture into collective farms, the Soviet government disorganized all the social life of the countryside, and destroyed invaluable capital goods accumulated by the well-to-do peasantry during the preceding ten years. An illustration may be found in the great decrease in the number of livestock in the year 1929-30, a decrease so formidable that it would seem incredible if it were not confirmed by many authoritative sources. ${ }^{24}$ During one year the number of horses decreased by 10 per cent, or 2,500,000 head, the number of cattle by one-fifth, or 15,000,000 head, the number of sheep by one-third, or $43,000,000$ head, the number of swine by two-fifths or $8,000,000$ head. Such a decrease of livestock in one year had never been known in Russian history. Even after the famine of 1921 the losses of livestock were smaller, although millions of human beings were lost. This decline in the number of livestock demonstrates clearly what a catastrophe occurred to Russian agriculture during the last winter. Trying to solve one problem, to increase grain production, the Soviet government destroyed a still more important, or at any rate, a branch of agriculture more difficult to recover. The policy of forced collectivization and the struggle against the well-to-do peasantry were responsible for

\footnotetext{
24 See speeches of Stalin and Jakovleff at the sixteenth congress of the communist party, Pravda, No. 177, June 29, 1930, and No. 190, July 12, 1930; also "Agrieultural Statistics of the U.S.S.R.," mentioned above.
} 
this catastrophe. The well-to-do peasant preferred to slaughter his livestock rather than to have it confiscated. The middle peasant, forced to join a collective farm, preferred before joining to sell or to slaughter his livestock, for if he brought it to the collective farm it was accepted at a very low valuation. ${ }^{25}$ Many peasants joining collective farms expected that the government would give them enough tractors and equipment to enable them to work their land. Official propaganda in some regions designed to promote collectives, was perhaps responsible for such a belief..$^{26}$

Now, in order to repair the damage to the livestock industry which its policy has caused, the Soviet government has started a new project of state organization of the livestock industry on huge state farms managed by the Trusts which have already been mentioned. These projects are still in their infancy and it is impossible to say anything definitive about them, except that the application of bureaucratic forms of organization to this branch of agriculture may well be considered as still more questionable than their application to the organization of grain production.

\section{Discussion by J. G. OHsol}

\section{NEW YORK}

I should like to ask Professor Timoshenko whether it would not be more correct to explain the recent farm collectivization policy of the Soviet government by the impossibility of coordinating large-scale planned state industry with twenty-four million small peasant farms with very fluctuating returns?

Furthermore, the very fact that within two years over five million small farms have been merged into collectives would seem to indicate that this process of collectivization has been supported by the bulk of the peasantry, else it would have been impossible to keep them together by any compulsory means. Likewise this year's increased returns of the grain harvest by 18 to 20 per cent certainly show that the large state grain and collective farms have met with appreciable suceess.

This fall, after the peasants became convinced that the collective farms really insure better yields and better returns for their labor they are applying in large numbers for the admission to collective farms.

Speaking of livestock farming, one should remember that model beef cattle and dairy farms in this country are found among the largest, not among the smallest farms. Would it not, therefore, be fair to assume that the Soviet Union might also succeed with the organization of large-scale livestock farms should we not rather await some positive proof before pronouncing any definite judgment?

\footnotetext{
${ }^{25}$ See article, "In the Regions of Thorough Collectivization," by M. Solomonov, mentioned above, p. 235 .

Ibid, pp. 235-236.
} 